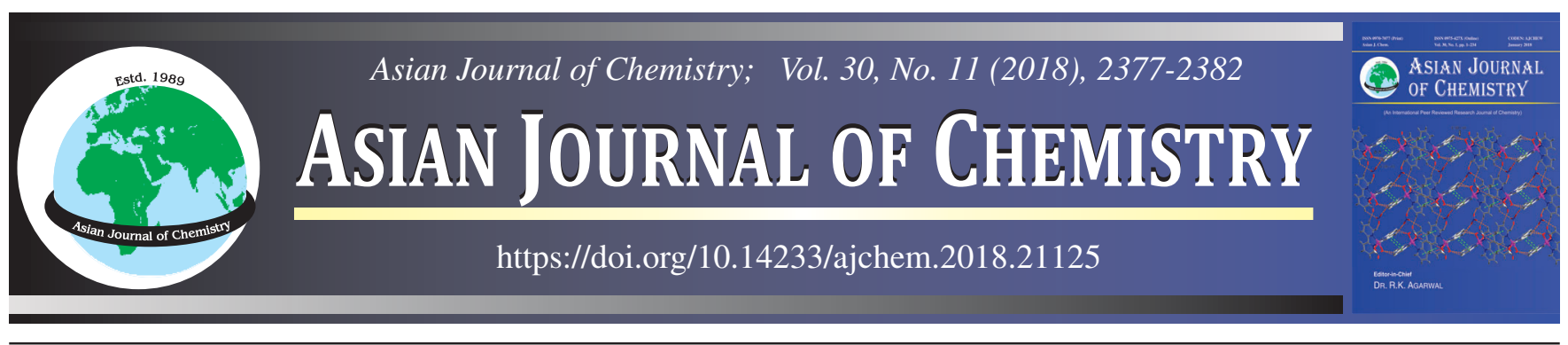

\title{
Synthesis and Molecular Docking Based Exploration of Salicylic Acid Derivatives
}

\author{
NAVNeEt Singh* and GeEtika Garg
}

Department of Chemistry, School of Chemical Engineering and Physical Sciences (Lovely Professional University), Phagwara-144 411, India

*Corresponding author: E-mail: drnavneet10@gmail.com

Received: 8 November 2017;

Accepted: 15 February 2018;

Published online: 27 September 2018;

AJC-19079

In present study, four salicylic acid derivatives viz., 2-acetoxybenzoic acid (2a), 2-(1H-indol-2-yl)benzoic acid (3a), 5-chloro-2acetoxybenzoic acid (2b) and 5-chloro-2-(1H-indol-2-yl)benzoic acid (3b) were synthesized and studied for molecular docking on 3JUS and 3UPI protein selected from pdb. The studies show that all of the four synthesized compounds were found to be docked. Compound 3a and 3b showed the best ligand pose energy $-10.8163 \mathrm{kcal} / \mathrm{mol}$ and $-11.1354 \mathrm{kcal} / \mathrm{mol}$ with docking run: elapsed time $9 \mathrm{~s}$ and $12 \mathrm{~s}$, respectively in respect of 3JUS Further, compounds 3a and 3b showed the best ligand pose energy -9.17851 and $-9.54722 \mathrm{kcal} / \mathrm{mol}$ with docking run: elapsed time 10 and 14 s, respectively in case of 3UPI. Hence, studies showed that 5-chloro-2-(1H-indol-2-yl)benzoic acid (3b) emerged as potent compound which might show diverse nature of biological and therapeutic activity.

Keywords: Salicylic acid, Benzoic acid, Molecular docking, Indole, Hydrazine.

\section{INTRODUCTION}

Salicylic acid is a natural occurring product which is present in the bark of the willow trees. Salicylic acid is present in the vast range of eukaryotic and prokaryotic organisms as well as in the plants. One major role which is established in plants is that salicylic acid acts as a signal molecule in plants for defense responses [1]. For more than 2000 years salicylic acid has been used to treat various skin disorders. It is a good agent as it has the ability to exfoliate Stratum corneum. For example acne can be treated using salicylic acid because it has antiinflammatory property [2]. Other disorders which can be treated using salicylic acid comprises of vulgaris, freckles, photo damage, malasma and lentigines [3]. Aspirin is an acetylated form of salicylic acid which has anti-inflammatory activity which is due to its ability to inhibit the production of proinflammatory prostaglandins. Aspirin is the most commonly used synthetic medicine, which is used to treat the pain and to prevent the cardiovascular disease [4]. Salicylic acid is the simplest aromatic carboxylic acid with the hydroxyl derivatives. Salicylic acid can be used to synthesize aspirin which further can be used to synthesize the derivative of indoles. The literature reviews of salicylic acid derivatives enlightened us about numbers of medicinal, pharmacological or therapeutic activities [5-17].
In preview of this observation, present work was the outcome of impression of diverse nature of biological activities of salicylic acid. The main purpose was to synthesize and characterize high purity aspirin followed by the formation of indole through cyclization. In this work, various salicylic acid originated derivatives were synthesized, screened by lab techniques and studied for molecular docking evaluation. The molecular docking study wasdone using ARGUS software with help of 3JUS and 3UPI proteins selected from $\mathrm{pdb}$. The molecular docking study revealed that synthesized compounds, 2-( $1 H$-indol-2-yl)benzoic acid (3a) and 5-chloro-2-(1H-indol-2-yl)benzoic acid (3b) showed potent biological activity.

\section{EXPERIMENTAL}

Melting points of synthesized compounds were determined by open capillary and are uncorrected. The purity of compounds was checked using TLC plates (glass) coated with silica gel. The developed chromatographic plates were visualized under iodine chamber. IR spectra were recorded using $\mathrm{KBr}$ on Shimadzu FTIR model 8400 spectrophotometer. ${ }^{1} \mathrm{H}$ NMR spectra and mass spectra was recorded through software Chemdraw. Molecular docking studies were carried out using Argus lab 4.0.1 software.

Synthesis of 2-acetoxybenzoic acid (2a): 2-Hydroxybenzoic acid $(0.01 \mathrm{~mol})$ was added in $100 \mathrm{~mL}$ beaker followed

This is an open access journal, and articles are distributed under the terms of the Creative Commons Attribution-NonCommercial 4.0 International (CC BY-NC 4.0) License, which allows others to copy and redistribute the material in any medium or format, remix, transform, and build upon the material, as long as appropriate credit is given and the new creations are licensed under the identical terms. 
by $2 \mathrm{~mL}$ of pyridine, the mixture was kept on ice bath and then cold $2 \mathrm{~mL}$ of acetyl chloride was added in mixture. Conc. $\mathrm{H}_{2} \mathrm{SO}_{4}(0.1 \mathrm{~mL})$ was added and the mixture was stirred and poured into $15 \mathrm{~mL}$ of distilled water. The reaction mixture was heated at $60{ }^{\circ} \mathrm{C}$ till dissolution then kept on ice bath till crystals were formed. The crystals were filtered, washed with cold water and recrystallized with ethanol to get fine crystals of 2-acetoxybenzoic acid (2a). Yield: $59.23 \%$ (180 g), m.w. $\mathrm{C}_{9} \mathrm{H}_{8} \mathrm{O}_{4}$, m.p. $150{ }^{\circ} \mathrm{C}, \mathrm{R}_{\mathrm{f}}$ : 0.5. Elemental analysis calcd. (found) (\%): $\mathrm{C} 60.00$ (60.00); H 4.46 (4.48), O 35.54 (35.52). FTIR (KBr, $\left.v_{\max }, \mathrm{cm}^{-1}\right)$ : $3238=\mathrm{C}-\mathrm{H}$ str. arom. ring) , 3100-2500 (OH str. COOH), 1658 $\left(\mathrm{C}=\mathrm{O}\right.$ str. $\left.\mathrm{COCH}_{3}\right), 1612(\mathrm{C}=\mathrm{O}$ str. $\mathrm{COOH}), 1483(\mathrm{C}=\mathrm{C}$ str. arom. ring), 1440 (C-H bend. arom. ring), 1296 (OH bend. carbonyl ). MS: m/z 180.04 (100.0\%), 181.05 (10.0\%), 182.05 (1.3\%).

Synthesis of 2-(1H-indol-2-yl)benzoic acid (3a): In this method, 2-(1H-indol-2-yl)benzoic acid (3a) was prepared by Shaikh et al. method [18]. The mixture of compound $\mathbf{2 a}(0.01$ $\mathrm{mol})$ and phenylhydrazene $(0.01 \mathrm{~mol})$ and $12 \mathrm{~mL}$ of ethanol was taken in round bottom flask. The reaction mixture was refluxed for $2-3 \mathrm{~h}$ at $25-30^{\circ} \mathrm{C}$, cooled at room temperature and poured into $8 \mathrm{~mL}$ conc. $\mathrm{H}_{2} \mathrm{SO}_{4}$. The mixture was then heated and stirred for 20-30 min and poured into $20 \mathrm{~mL}$ of ice cold water to get solid product. The crystals were filtered, dried and recrystallized with methanol. Yield: $38.81 \%(273 \mathrm{~g})$, m.w. $\mathrm{C}_{15} \mathrm{H}_{11} \mathrm{O}_{2} \mathrm{~N}$, m.p. $170{ }^{\circ} \mathrm{C}, \mathrm{R}_{\mathrm{f}}$ : 0.9. Elemental analysis calcd. (found) (\%): $\mathrm{C}$ 75.80 (75.90); H 4.60 (4.60), N 5.90 (5.90), O 13.35 (13.40). FTIR $\left(\mathrm{KBr}, v_{\max }, \mathrm{cm}^{-1}\right): 3438$ (NH str. $\left.-\mathrm{NH}=\mathrm{N}-\right)$ 2607, 2488, 2360 (Ar overtones), 2889 (C-H str. arom. ring), 1604 (C=C str. arom. ring), 688, 742 (C-H bend. arom. bend.). MS: $m / z 210.12$ (100.0 $\%), 211.12(15.1 \%), 212.12(1.1 \%)$.

Synthesis of 5-chloro-2-acetoxybenzoic acid (2b): 5Chloro-2-hydroxybenzoic $(0.02 \mathrm{~mol}), 2 \mathrm{~mL}$ of pyridine and 4 $\mathrm{mL}$ of toluene were heated till dissolution in $100 \mathrm{~mL}$ beaker. Then $2 \mathrm{~mL}$ of cold acetyl chloride was added followed by the addition of $0.1 \mathrm{~mL}$ of conc. $\mathrm{H}_{2} \mathrm{SO}_{4}$. The reaction mixture was stirred and poured into $15 \mathrm{~mL}$ of distilled water. It was then heated at $60^{\circ} \mathrm{C}$ till dissolution got completed and mixture was kept on ice bath to get crystals. The crystals were filtered, washed and dried. The recrystallization with ethanol yielded pure crystals of 5-chloro-2-acetoxybenzoic acid (2b). Yield: 95.60 $\%$ (214.5 g), m.w. $\mathrm{C}_{9} \mathrm{H}_{7} \mathrm{O}_{4} \mathrm{Cl}$, m.p. $80{ }^{\circ} \mathrm{C}, \mathrm{R}_{\mathrm{f}}$ : 0.9. Elemental analysis calcd. (found) (\%): C 50.48 (50.38), H 3.53 (3.29),
Cl 16.60 (16.52), O 29.40 (29.81). FTIR (KBr, $\left.v_{\max }, \mathrm{cm}^{-1}\right): 3236$ (C-H str. arom. ring), 3300 (O-H str.), 1454 (C=C str. arom. ring), 1300 (C-C str.), 1233 (C-H bend.), 890 (O-H bend.), 800-500 (=C-H bend.). MS: $m / z, 214.00$ (100.0\%), 216.00 (32.0\%), 215.01 (10.0\%), 217.00 (3.2\%), 216.01 (1.3\%).

Synthesis of 5-chloro-2-(1H-indol-2-yl)benzoic acid (3b): In this method, 5-chloro-2-(1H-indol-2-yl)benzoic acid (3b) was prepared by Shaikh et al. method [18]. The mixture of compound $\mathbf{2 b}(0.01 \mathrm{~mol})$, phenylhydrazene $(0.01 \mathrm{~mol})$ and $12 \mathrm{~mL}$ of ethanol was refluxed for $2-3 \mathrm{~h}$ at $25-30^{\circ} \mathrm{C}$, cooled at room temperature and poured into $8 \mathrm{~mL}$ conc. $\mathrm{H}_{2} \mathrm{SO}_{4}$. The reaction mixture was then heated, stirred for 20-30 min and then poured into $20 \mathrm{~mL}$ of ice cold water to get solid product. The crystals were filtered, dried and recrystallized with methanol. Yield: $50.00 \%$ (272.5 g), m.w. $\mathrm{C}_{15} \mathrm{H}_{11} \mathrm{O}_{2} \mathrm{NCl}$, m.p. $170{ }^{\circ} \mathrm{C}, \mathrm{R}_{\mathrm{f}}$ : 0.82. Elemental analysis calcd. (found) (\%): C 66.80 (66.30); H 4.60 (3.71), N 5.90 (5.16), Cl 11.35 (13.0), O 11.35 (11.78). FTIR $\left(\mathrm{KBr}, v_{\max }, \mathrm{cm}^{-1}\right)$ : 3449 (NH str. $\left.-\mathrm{NH}=\mathrm{N}-\right)$ 2607, 2488, 2360 (Ar overtones), 2889 (C-H str. arom. ring), 1604 (C=C str. arom. ring), 688, 742 (C-H bend. arom. bend.). MS: $m / z 210.12$ (100.0 $\%), 211.12(15.1 \%), 212.12(1.1 \%)$.

Molecular docking study: The molecular docking calculations was carried out using ArgusLab software. The molecular docking studies revealed that ligand of respective synthesized compounds $\mathbf{2} \mathbf{a}-\mathbf{b}$ and $\mathbf{3} \mathbf{a}-\mathbf{b}$ had been found docked successfully with H-bonding on the binding site (amino acids) of 3JUS (Figs. 1-4) and 3UPI protein (Figs. 5-8), selected from pdb. The best ligand pose energies had been quite remarkable in case of 3JUS as listed in Table-1. The best ligand pose energies had also been quite remarkable in case of 3UPI (Table-2).

\section{RESULTS AND DISCUSSION}

The interesting outcome of this work is the synthesis of indoles through salicylic acid followed by cyclization (Scheme-I). Though, low yield has been a matter of concern. As shown in the highlighted case studies, molecular docking has been able to identify promising compounds that might represent future solutions in critical areas of human health. The compounds, 2-(1H-indol-2-yl)benzoic acid (3a) and 5-chloro-2-( $1 H$-indol2-yl)benzoic acid (3b) showed promising activity of varying degree. The compound $\mathbf{3 a}$ had been found docked with binding amino acids such as 752 GLY:coil, 580 THR:alpha helix etc.
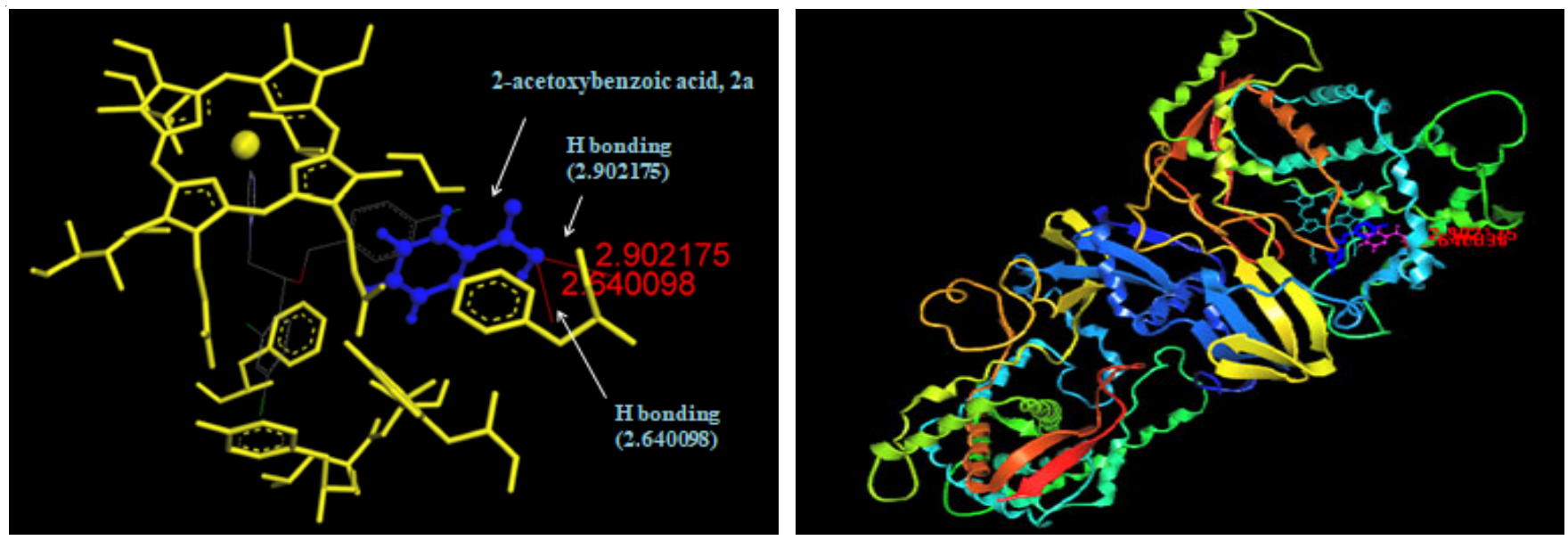

Fig. 1. Molecular docking of colour ribbon as chain position and render protein as cartoon ribbon for compound 2a with 3JUS 


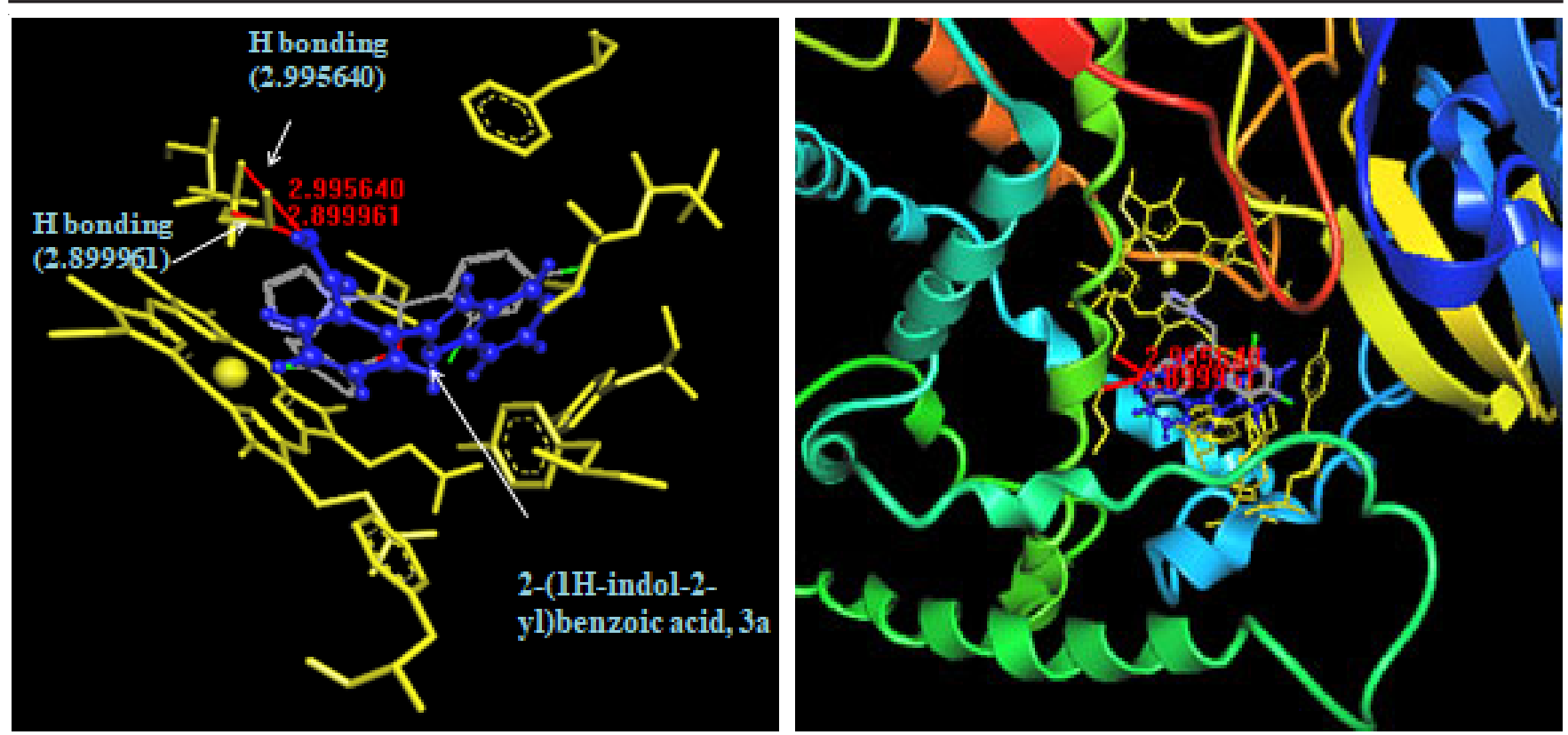

Fig. 2. Molecular docking of colour ribbon as chain position and render protein as cartoon ribbon for compound 3a with 3JUS
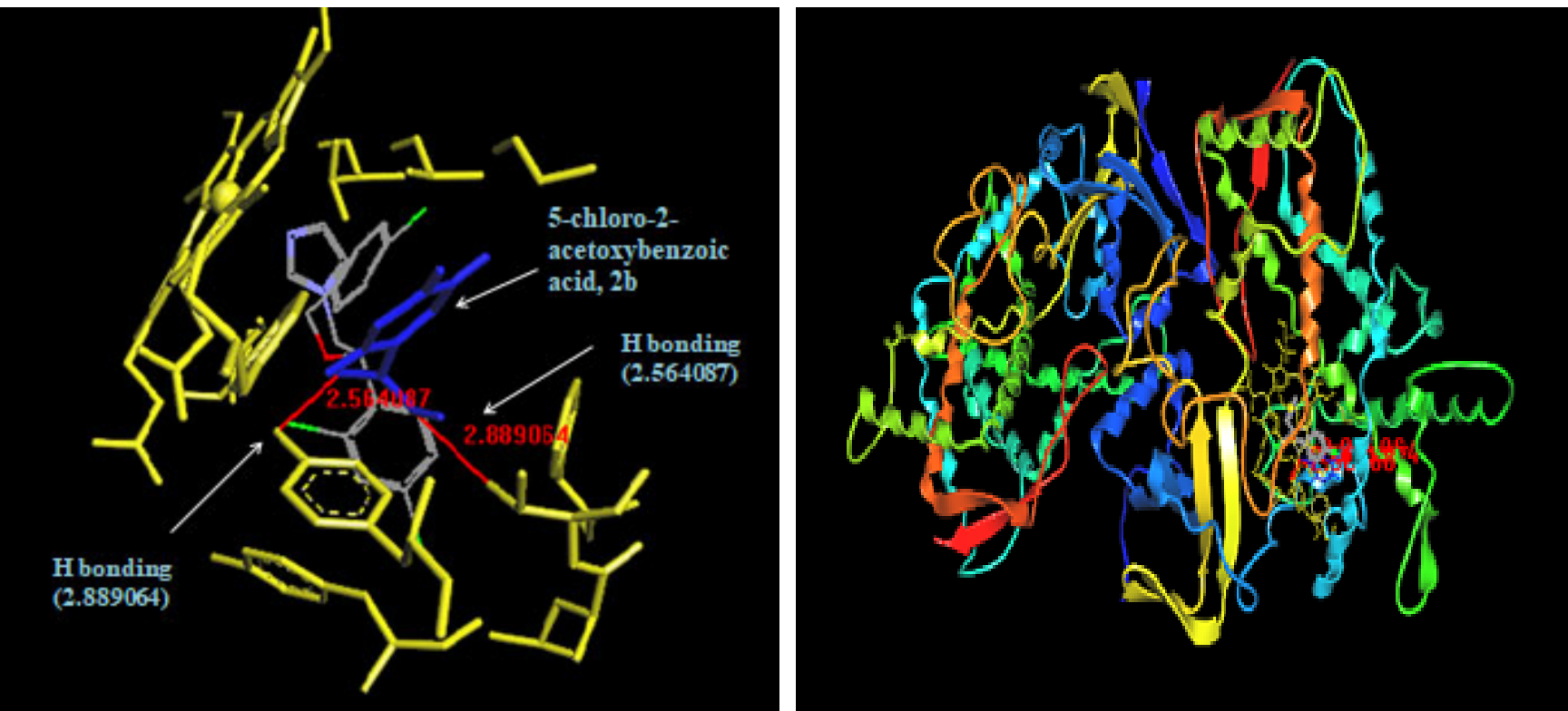

Fig. 3. Molecular docking of colour ribbon as chain position and render protein as cartoon ribbon for compound $\mathbf{2 b}$ with $3 \mathrm{JUS}$
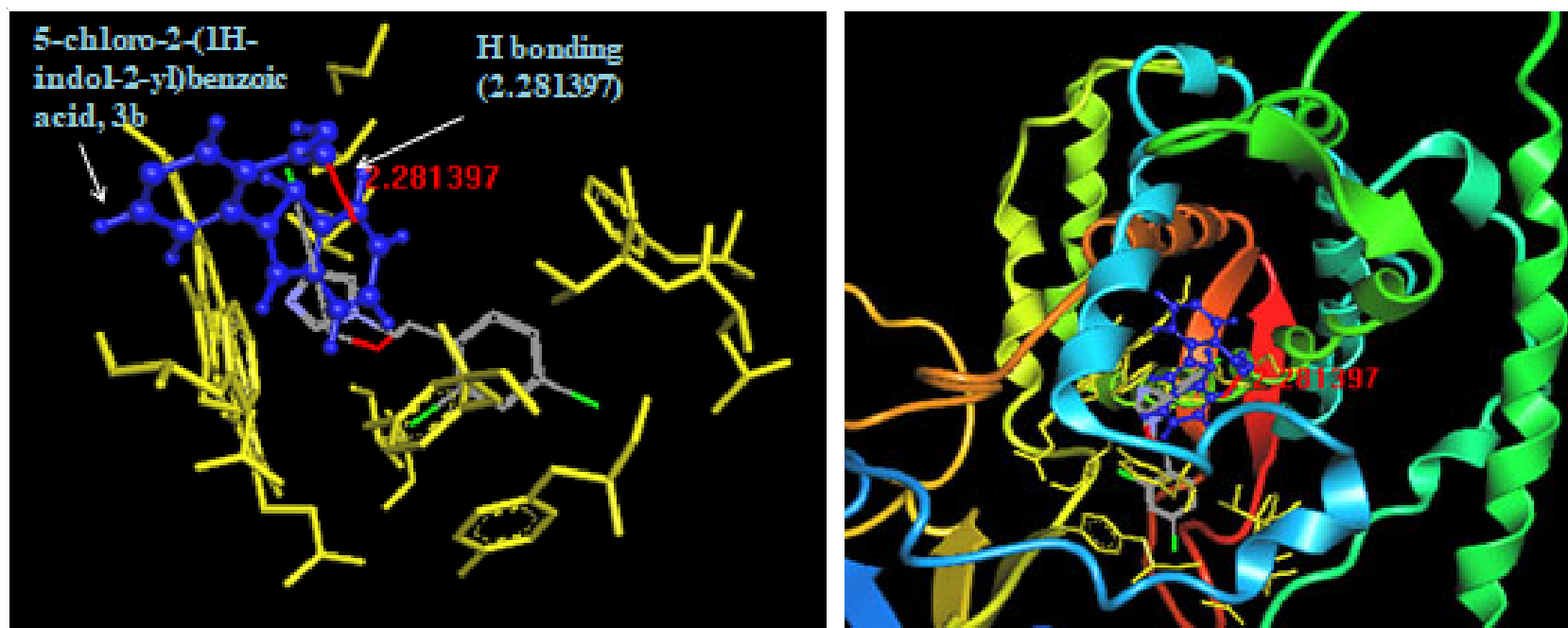

Fig. 4. Molecular docking of colour ribbon as chain position and render protein as cartoon ribbon for compound $\mathbf{3 b}$ with $3 \mathrm{JUS}$ 

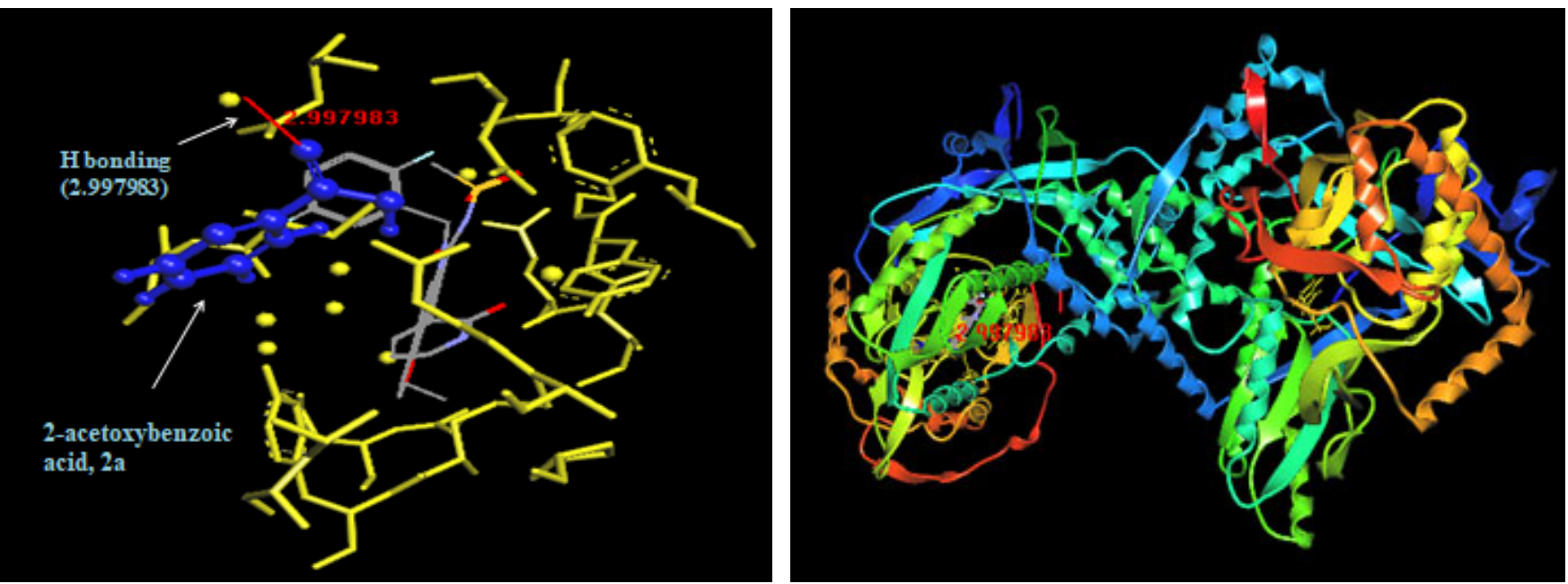

Fig. 5. Molecular docking of colour ribbon as chain position and render protein as cartoon ribbon for compound $2 \mathbf{a}$ with 3 UPI
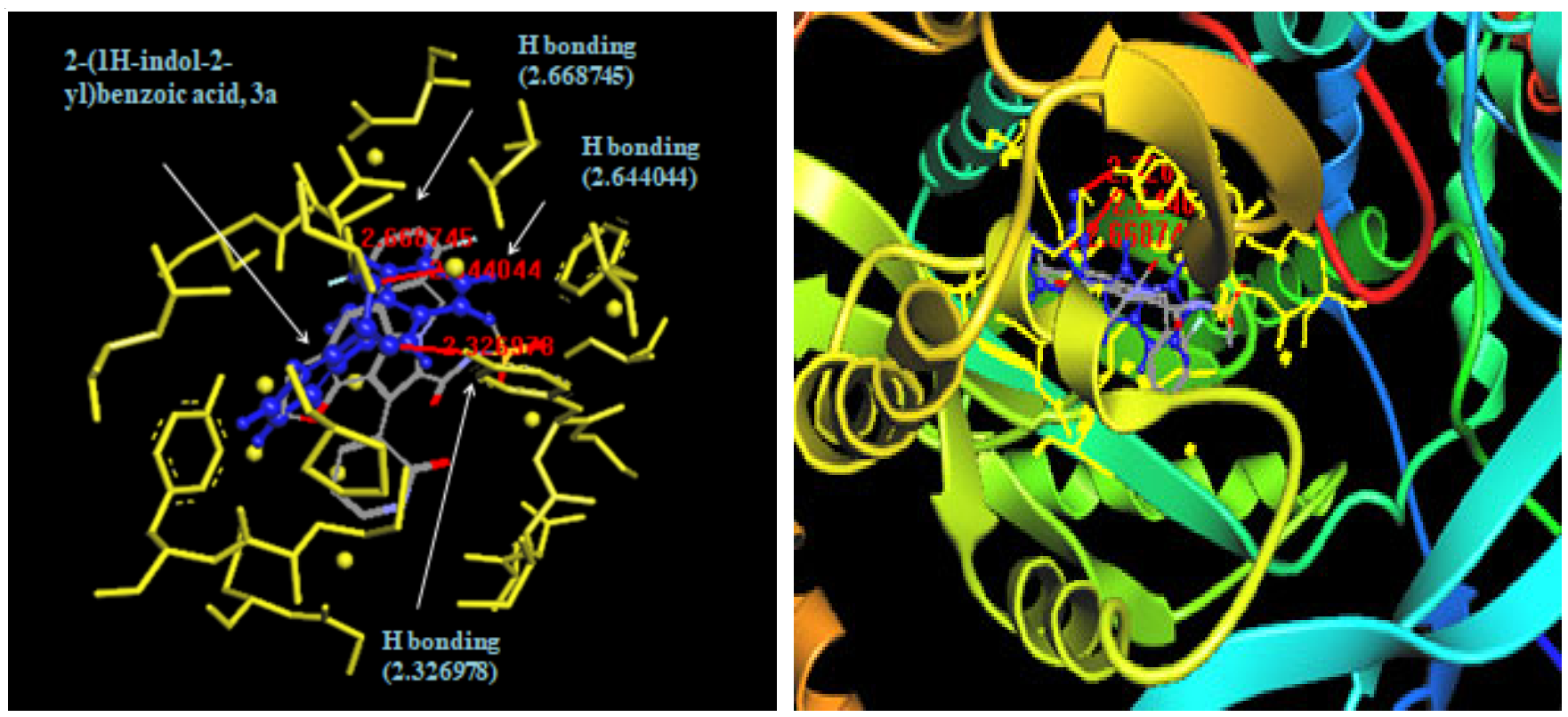

Fig. 6. Molecular docking of colour ribbon as chain position and render protein as cartoon ribbon for compound 3a with 3UPI
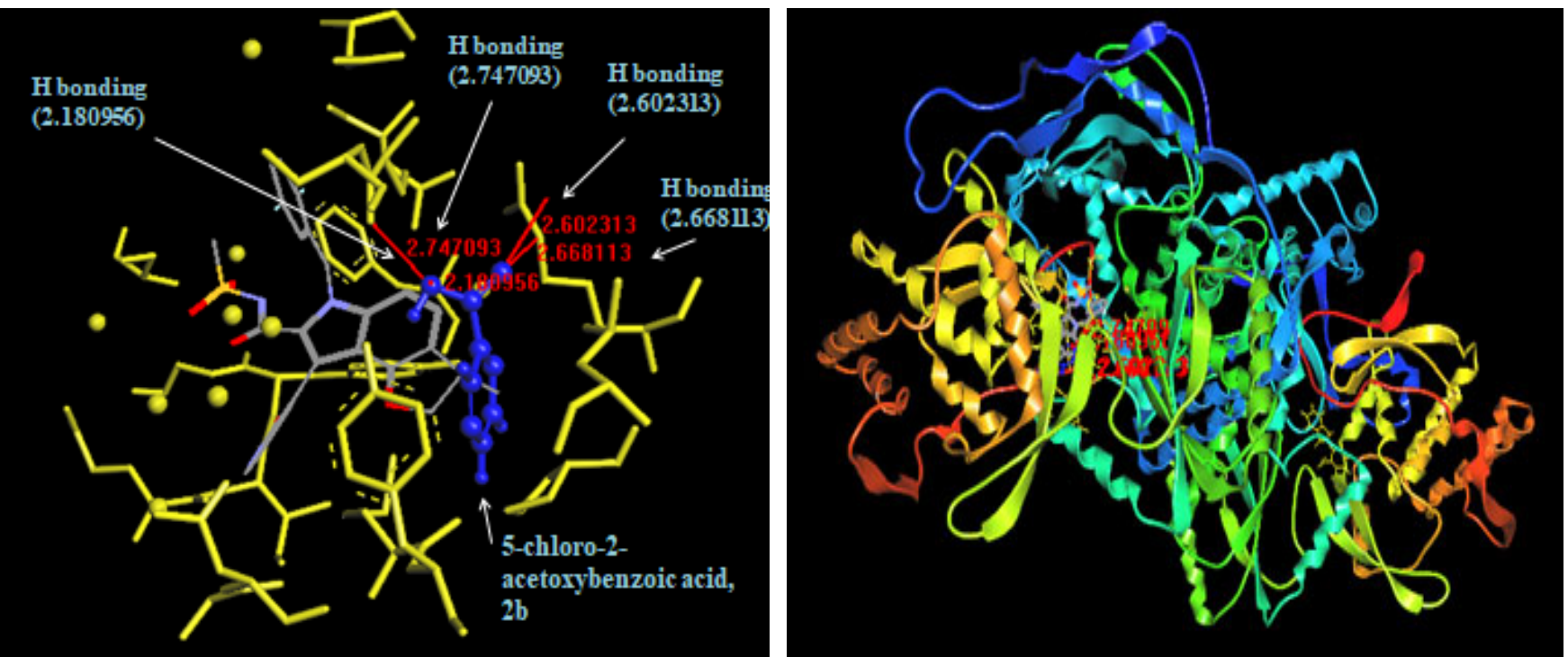

Fig. 7. Molecular docking of colour ribbon as chain position and render protein as cartoon ribbon for compound $2 \mathbf{b}$ with 3 UPI 

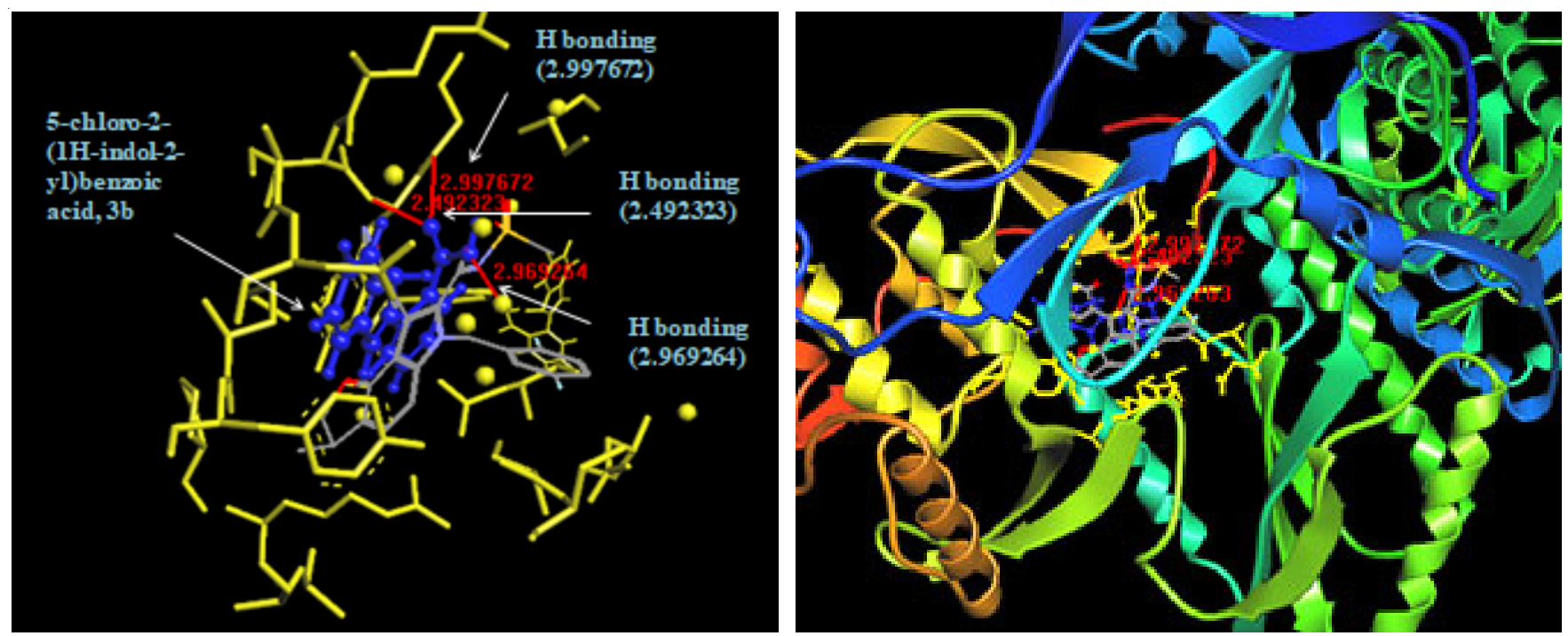

Fig. 8. Molecular docking of colour ribbon as chain position and render protein as cartoon ribbon for compound $\mathbf{3 b}$ with 3 UPI

TABLE-1

MOLECULAR DOCKING STUDIES OF SYNTHESIZED COMPOUNDS WITH TARGET PROTEIN 3JUS

\begin{tabular}{|c|c|c|c|c|c|}
\hline Compd. & $\begin{array}{l}\text { Clustering the } \\
\text { final poses }\end{array}$ & $\begin{array}{c}\text { Best ligand pose; } \\
\text { energy }\end{array}$ & $\begin{array}{l}\text { Docking run: } \\
\text { Elapsed time }\end{array}$ & $\begin{array}{c}\text { Few binding amino } \\
\text { acids }\end{array}$ & H-bonding \\
\hline $2 a$ & 76 & $-8.5891 \mathrm{kcal} / \mathrm{mol}$ & $14 \mathrm{~s}$ & $\begin{array}{l}579 \text { LEU: alpha helix } \\
590 \text { TYR: coil }\end{array}$ & $\begin{array}{l}2.640098 \\
2.902175\end{array}$ \\
\hline $3 \mathbf{a}$ & 39 & $-10.8163 \mathrm{kcal} / \mathrm{mol}$ & $9 \mathrm{~s}$ & $\begin{array}{l}752 \text { GLY: coil, } \\
\text { 580THR: alpha helix }\end{array}$ & $\begin{array}{l}2.995640 \\
2.899961\end{array}$ \\
\hline $2 \mathbf{b}$ & 81 & $-8.06182 \mathrm{kcal} / \mathrm{mol}$ & $12 \mathrm{~s}$ & $\begin{array}{l}579 \text { LEU: alpha helix } \\
590 \text { TYR: coil }\end{array}$ & $\begin{array}{l}2.889064 \\
2.564087\end{array}$ \\
\hline $\mathbf{3 b}$ & 39 & $-11.1354 \mathrm{kcal} / \mathrm{mol}$ & $12 \mathrm{~s}$ & 756 ALA: alpha helix & 2.281397 \\
\hline
\end{tabular}

TABLE-2

MOLECULAR DOCKING STUDIES OF SYNTHESIZED COMPOUNDS WITH TARGET PROTEIN 3UPI

\begin{tabular}{|c|c|c|c|c|c|}
\hline Compd. & $\begin{array}{l}\text { Clustering the } \\
\text { final poses }\end{array}$ & $\begin{array}{c}\text { Best ligand pose; } \\
\text { energy }\end{array}$ & $\begin{array}{l}\text { Docking run: } \\
\text { Elapsed time }\end{array}$ & $\begin{array}{l}\text { Few binding } \\
\text { amino acids }\end{array}$ & H-bonding \\
\hline $2 a$ & 74 & $-8.14089 \mathrm{kcal} / \mathrm{mol}$ & $18 \mathrm{~s}$ & 973 GLY: alpha helix & 2.997983 \\
\hline $3 \mathbf{a}$ & 50 & $-9.17851 \mathrm{kcal} / \mathrm{mol}$ & $10 \mathrm{~s}$ & $\begin{array}{l}763 \text { AGR: alpha helix } \\
1009 \text { GLY: beta strand } \\
978 \text { TYR: coil }\end{array}$ & $\begin{array}{l}2.326978 \\
2.644044 \\
2.668745\end{array}$ \\
\hline $2 b$ & 71 & $-8.01004 \mathrm{kcal} / \mathrm{mol}$ & $14 \mathrm{~s}$ & $\begin{array}{l}879 \text { ASN: beta strand } \\
\text { 1009 GLN: beta strand } \\
\text { 973 GLY: alpha helix } \\
1011 \text { TYR: coil }\end{array}$ & $\begin{array}{l}2.602313 \\
2.668113 \\
2.747093 \\
2.180956\end{array}$ \\
\hline $3 b$ & 44 & $-9.54722 \mathrm{kcal} / \mathrm{mol}$ & $14 \mathrm{~s}$ & $\begin{array}{l}763 \text { AGR: alpha helix } \\
1009 \text { GLY: beta strand } \\
978 \text { TYR: coil }\end{array}$ & $\begin{array}{l}2.969264 \\
2.492323 \\
2.997672\end{array}$ \\
\hline
\end{tabular}<smiles>[R]c1ccc(O)c(C(=O)O)c1</smiles>

(1)<smiles>[R]c1ccc(OC(C)=O)c(C(=O)O)c1</smiles>

(2a-b)

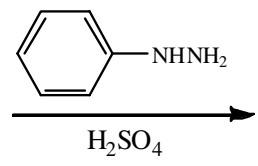

$\mathrm{R}=\mathrm{H}, \mathrm{Cl}$

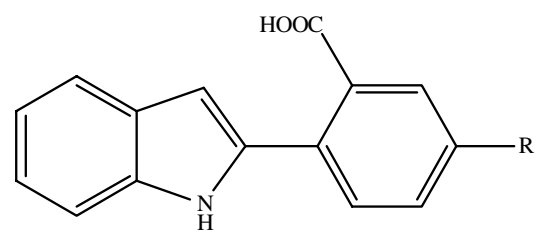

(3a-b)

Scheme-I

through H-bonding (2.995640 and 2.899961) with best ligand pose energy $-10.8163 \mathrm{kcal} / \mathrm{mol}$ with docking run: elapsed time 9 swith 3JUS protein (Fig. 2). Further, compound 3a had been found docked with binding amino acids such as 763 AGR:alpha helix, 1009 GLY: beta strand, 978 TYR:coil, etc. through H- bonding $(2.326978,2.644044$ and 2.668745$)$ with best ligand pose energy $-9.17851 \mathrm{kcal} / \mathrm{mol}$ with docking run: elapsed time $10 \mathrm{~s}$ with 3UPI protein (Fig. 6). Compound $\mathbf{3 b}$ had been found docked with binding amino acid 756 ALA:alpha helix through H-bonding (2.281397) with best ligand pose energy -11.13541 
$\mathrm{kcal} / \mathrm{mol}$ with docking run: elapsed time $12 \mathrm{~s}$ with $3 J U S$ protein (Fig. 4). Further compound $\mathbf{3 b}$ had been found docked with binding amino acids such as 763 AGR: alpha helix, 1009 GLY:beta strand, 978 TYR:coil through H-bonding (2.969264, 2.492323 and 2.997672) with best ligand pose energy -9.547221 $\mathrm{kcal} / \mathrm{mol}$ with docking run: elapsed time $14 \mathrm{~s}$ with 3UPI protein (Fig. 8). The present work clearly stated about few synthesized new salicylic acid derivatives and their pharmacological profiles which may contribute in future to synthesize various analogues and to develop new less toxic pharmacological drugs.

\section{ACKNOWLEDGEMENTS}

The authors are grateful to Dr. Ramesh Chand Thakur, HOD, Department of Chemistry, School of Chemical Engineering and Physical Sciences for encouragement and necessary guidance and also to Lovely Professional University for providing research facilities.

\section{CONFLICT OF INTEREST}

The authors declare that there is no conflict of interests regarding the publication of this article.

\section{REFERENCES}

1. D.M.A. Dempsey, J. Shah and D.F. Klessig, Crit. Rev. Plant Sci., 18, 547 (1999); https://doi.org/10.1080/07352689991309397.

2. A. Krautheim and H. Gollnick, Clin. Pharmacokinet., 42, 1287 (2003); https://doi.org/10.2165/00003088-200342140-00005.

3. T. Arif, Clin. Cosmet. Investig. Dermatol., 8, 455 (2015); https://doi.org/10.2147/CCID.S84765.

4. J.R. Vane and R.M. Botting, Thromb. Res., 110, 255 (2003); https://doi.org/10.1016/S0049-3848(03)00379-7.
5. R.S. Borges, T.G. Barros, G.A.N. Pereira, J. Batista Jr., R.F.G.P. Beleza Filho, A.A.S. Veiga, M. Hamoy, V.J. Mello, A.B.F. Silva and C.A.L. Barros, Pharmacol. Pharm., 5, 1185 (2014); https://doi.org/10.4236/pp.2014.513130.

6. C.J. Patil and C.A. Nehete, Int. J. Pharm. Sci. Rev. Res., 33, 248 (2015).

7. M.J.M. Taka and D.V. Topic, Acta Pharm., 54, 171 (2004).

8. D.F. Klessig, M. Tian and H.W. Choi, Front. Immunol., 7, 206 (2016); https://doi.org/10.3389/fimmu.2016.00206.

9. Y. Anjaneyulu, N.B. Ramam and R.P. Rao, Indian Natl. Sci. Acad., 53, 548 (1987).

10. R. Dachineni, D.R. Kumar, E. Callegari, R. Sankaranarayanan, S.S. Kesharwani, T. Seefeldt, H. Tummala and G.J. Bhat, Int. J. Oncol., 51, 1661 (2017); https://doi.org/10.3892/ijo.2017.4167.

11. A. Wodnicka and E. Huzar, Curr. Chem. Lett., 6, 125 (2017); https://doi.org/10.5267/j.ccl.2017.3.002.

12. A. Imramovsky, K. Pauk, Z. Padelkova and J. Hanusek, Crystals, 2, 349 (2012); https://doi.org/10.3390/cryst2020349.

13. D. Ekinci, M. Senturk and O. Kufrevioglu, Expert. Opin. Ther. Pat., 21, 1831 (2011); https://doi.org/10.1517/13543776.2011.636354.

14. P.M. Chagas, S.G. Rosa, M.H. Sari, C.E. Oliveira, R.F. Canto, S.C. da Luz, A.L. Braga and C.W. Nogueira, Pharmacol. Biochem. Behav., 118, 87 (2014); https://doi.org/10.1016/j.pbb.2013.12.022.

15. P.S. Clissold, Drugs, 32(Suppl. 4), 8 (1986); https://doi.org/10.2165/00003495-198600324-00003.

16. O.O. Fadeyi, C.A. Obafemi, C.O. Adewunmi and E.O. Iwalewa, Afr. J. Biotechnol., 3, 426 (2004); https://doi.org/10.5897/AJB2004.000-2081.

17. A. Saqib, C.S. Karigar, M.A. Pasha and M.S.R. Harish, J. Pharmacol. Res. Opin., 2, 35 (2012).

18. S. Shaikh, N. Shaikh, M. Zamir, S.D. Salunke and M.A. Baseer, Chem. Sci. Trans., 2, 584 (2013); https://doi.org/10.7598/cst2013.427. 